\title{
Precision Teaching and Learning Performance in a Blended Learning Environment
}

\author{
Bin Yin* and Chih-Hung Yuan* \\ School of Economics and Commerce, University of Electronic Science and Technology of China, Zhongshan Institute, \\ Zhongshan, China
}

Blended learning has gained increasing popularity in colleges and universities with mixed results. Precision teaching can effectively promote learning performance. The relation between perceived precision teaching (PPT) and the learning performance of college students in a blended learning environment is investigated in this paper. In the research survey is featuring a structural model, 256 college students who attended blended learning courses featuring precision teaching participated. The model results revealed that PPT is directly and positively related to self-efficacy and learning motivation. Self-

OPEN ACCESS

Edited by:

Myint Swe Khine,

Curtin University, Australia

Reviewed by:

Manyu $\mathrm{Li}$,

University of Louisiana at Lafayette,

United States

Gila Zilka,

Bar-Ilan University, Israel

*Correspondence:

Bin Yin

9154748@qq.com

Chih-Hung Yuan

ialexyuan@gmail.com

Specialty section:

This article was submitted to Educational Psychology, a section of the journal

Frontiers in Psychology

Received: 19 November 2020 Accepted: 12 January 2021

Published: 05 February 2021

Citation:

Yin B and Yuan C-H (2021) Precision Teaching and Learning Performance in a Blended Learning

Environment.

Front. Psychol. 12:631125. doi: 10.3389/fpsyg.2021.631125 efficacy and learning motivation are directly and positively related to cognitive, teaching, and social presence. Additionally, cognitive, teaching, and social presence are directly and positively related to learning performance. Therefore, PPT is remotely and indirectly related to learning performance. These findings provide a new perspective for the theoretical study on blended learning performance and provide a realistic reference for precision teaching practice in the blended learning environment. Keywords: blended learning, precision teaching, self-efficacy, learning motivation, community of inquiry, learning
performance, structural equation modeling

\section{INTRODUCTION}

Blended learning, as a combination of traditional face-to-face learning and online learning, is aimed at creating a learning atmosphere in support of self-oriented learning, and it claims many benefits (Garrison and Kanuka, 2004; Alammary et al., 2014) such as improving learning efficiency, satisfaction, and learning performance. A long-range research survey conducted by the University of Central Florida (UCF) measured the success of tens of thousands of students in face-to-face learning, blended learning, and online learning environments. UCF defines success as obtaining a Grade C, at least. Factors such as the students' college, gender, and financial means were also considered. The UCF reported that, for each college, blended learning has a higher success rate than face-to-face learning or online learning (Dziuban et al., 2004). Blended learning may also reinforce flexibility (Moskal et al., 2013; Alammary, 2019) while providing more opportunities for students to access higher education and simultaneously allowing the school to have more contact with students (Vaughan, 2007; Erbil, 2020). Blended learning can also allow for greater spatial and temporal flexibility of both teachers and students so that they have the freedom to decide when and where to organize online teaching and learning (Sharpe et al., 2006; King and Arnold, 2012). It also helps to improve cost-effectiveness and resource use rate (Moskal et al., 2013). In comparison with face-to-face teaching, blended teaching is more likely to further cut operating costs down 
(Vaughan, 2007). By promoting more students to select courses and the use of network facilities, blended learning requests less classroom time than face-to-face courses, and maintains a greater student retention rate than online courses, thus reducing the time required for students to complete the degree (King and Arnold, 2012; Yuan and Wu, 2020). Blended learning has gained increasing popularity in colleges and universities (Alammary et al., 2014; Porter et al., 2014; Ghazal et al., 2018).

Empirical studies on the learning performance of blended learning derive mixed results. Shea and Bidjerano (2014) discovered that senior high school graduates who received some online or remote courses from American community colleges have a greater probability to obtain the certificate than their peers who solely attended classroom teaching. At the University of Granada, the introduction of blended learning into basic accounting courses raised students' exam results and lowered their dropout rate (Victoria Lopez-Perez et al., 2011). Students seemingly hold a positive attitude toward it. Jones and Chen (2008) reported students' positive experiences in blended MBA accounting courses. The negative effect of blended learning is reported by other studies ( $\mathrm{Xu}$ and Jaggars, 2011). Numerous studies further reveal learners' problems with persistence in online and blended learning environments, which can be evidenced by a greater dropout rate compared with traditional face-to-face teaching (Xenos et al., 2002; Levy, 2007). Thus, it is necessary to set forth the related factors associated with learning performance in blended learning environments (Ramirez-Arellano et al., 2018).

Scholars have discussed many factors related to learning performance, such as the fundamental individual factors of learners, learning motivation, learning performance expectations, learning time investment ( $\mathrm{Hsu}$ and Hsieh, 2011; Dakduk et al., 2018; Law et al., 2019), the self-regulating learning ability in the learning process (Sabah, 2020), learning attitude (Hsu and Hsieh, 2011), and prior experience of online learning (Lim and Morris, 2009) all predict learning performance. Regarding course factors, course content, structure clarity, course teaching methods, and modes of teaching predict learning performance (So and Brush, 2008; Afacan, 2016; Putri et al., 2019). As for learning support, a perceived learning system serviceability, usability, perceived flexibility, convenience for collaborative learning (Kerzic et al., 2019; Sabah, 2020), interactivity (Blieck et al., 2019), information support and process guidance (Cocquyt et al., 2019), and emotional support (So and Brush, 2008) predict learning performance.

Despite the many efforts made to figure out factors related to learning performance, few studies have paid attention to precision teaching. Precision teaching is defined as a method that monitors students' ability to access education. By monitoring students' learning process results, teachers can adjust their teaching and intervention measures to ensure the optimal learning performance of students (Rebecca and Michelle, 2016). Precision teaching may obviously promote learning performance (Datchuk, 2017; Mannion and Griffin, 2018). With the extensive application of information technology in the education industry, teachers can more conveniently monitor students' learning process results, make decisions on this basis (Bruhn et al., 2020), and timely adjust their teaching intervention measures to promote learning performance. Information technology has laid a good foundation for the effective implementation of precision teaching (Kubina and Yurich, 2012).

This research explores the relation between perceived precision teaching (PPT) and learning performance in blended learning environments. Self-efficacy and learning motivation are both related to learning performance (Bandura and Watts, 1995; Schneider and Preckel, 2017; Law and Geng, 2018). As a major theoretical model concerning blended learning, a community of inquiry (COI), is composed of social, teaching, and cognitive presence which all predict learning performance (Law et al., 2019). To deepen the correlation among PPT, self-efficacy, learning motivation, and COI, questions have been proposed for further research as below:

Q1: How does PPT predict learning performance in blended learning?

Q2: In blended learning, what is the role of self-efficacy, learning motivation, and COI (including social presence, teaching presence, and cognitive presence) in the relation between PPT and learning performance?

To address the aforementioned research questions, the researchers interviewed 256 students who attended blended course learning featuring precision teaching and performed a modeling analysis on the survey results using structural equation modeling (SEM) to conclude the relationship between PPT and learning performance in blended learning environments. The research aims to provide a realistic reference for the development of precision teaching practice for blended learning environments.

Subsequent chapters of the paper first review the relevant literature related to the theoretical foundation, put forward research hypotheses, materials and methods, following a report on the results for further discussion, and finally draw a conclusion and points out the research significance.

\section{THEORETICAL BACKGROUND}

\section{Blended Learning}

Accompanying the application of information and network technology, blended learning is becoming more popular in colleges and universities. Apart from the changes in the traditional face-to-face learning mode, blended learning makes full use of the convenience and rich resources of the internet, and combines this with the advantages of traditional learning. It is a new learning mode that reinforces teaching by computer and network online activities in traditional courses (BenbunanFich, 2008). The adoption of blended learning symbolizes the restructuring of curriculum design, which is intended for mobilizing students' initiative in participating in online learning.

Some studies have proven that integrating information technology into the teaching and learning process creates the acquisition of course resource information and the improvement of the learning experience (Bai et al., 2016; Darling-Aduana and Heinrich, 2018; Turvey and Pachler, 2020). Blended learning methods are also able to significantly enhance the learning 
experience. With a higher course satisfaction rate than traditional classroom teaching (Darling-Aduana and Heinrich, 2018), the learning method makes students more devoted to the learning process (Yildirim, 2005), and thus it is preferred by students for its greater flexibility and convenience (Hogarth, 2010). A blended learning course design is a sophisticated topic that involves numerous factors, among which learning experience is a predominant factor.

\section{Learning Performance}

Learning performance can be defined in different ways. For instance, it can refer to students' test scores (Ferguson and DeFelice, 2010; Ekwunife-Orakwue and Teng, 2014; Law and Geng, 2019), satisfaction with learning (Ekwunife-Orakwue and Teng, 2014; Yuan et al., 2020), or even their performance logged in the online learning system (Yang et al., 2016). This research adopts the definition of learning performance as described by the Association for Educational Communications and Technology in 2004, which states that learning performance is the ability of a learner to apply the newly acquired knowledge or skills. In essence, it does not solely involve the basic knowledge and skills learned, but the capability to apply them. There are many factors for learning performance (Broadbent, 2017; Li and Tsai, 2017; Li et al., 2018; Wei and Chou, 2020). In blended learning, COI is an essential theoretical model. With a focus on PPT, this research combines the dimensions in COI, such as teaching presence, social presence, and cognitive presence to investigate the relationship with learning performance. The research also examines the link between these dimensions and other learning characteristics.

\section{Precision Teaching}

Originating from America in the 1960s, precision teaching has been propagated in Britain by education psychologists (EPS) since the 1980s (Muncey and Williams, 1981; Raybould and Solity, 1982, 1988). It essentially pertains to a method of teaching that monitors students' acquisition of basic education skills. Through monitoring students' learning process results, teachers are capable of adjusting their teaching and intervention measures to ensure the optimal learning performance of students (Rebecca and Michelle, 2016). Precision teaching involves four basic steps: Pinpoint, Record, Change, and Try Again (Kubina and Yurich, 2012).

Precision teaching, as an effective method to reinforce students' acquisition of basic education skills (Chapman et al., 2005; Gist and Bulla, 2020), can stimulate students' learning motivation and get students more engaged in learning (Rebecca and Michelle, 2016). Precision teaching resounds to the improvement of learning performance (Datchuk, 2017; Mannion and Griffin, 2018).

\section{Perceived Precision Teaching}

Perceived precision teaching is defined as the learners' perception of precision teaching during their study, including the perception of the four basic steps, that is, deciding targeted learning goals, recording the learning process, teaching with purpose, and reexamining the attainment of goals (Pinpoint, Record, Change, and Try Again). PPT can be measured by surveying learners (Dibbs et al., 2013; Rebecca and Michelle, 2016).

\section{Self-Efficacy}

Self-efficacy indicates the individual belief in the success of performing a task (Bandura and Adams, 1980), which directly affects an individual's behavioral motivation in the implementation of a specific activity. Generally speaking, a successful experience consolidates self-efficacy, while recurrent failures damage self-efficacy.

Self-efficacy is often divided into universal self-efficacy and task-based self-efficacy (Sherer et al., 1982), of which the latter is suited to given tasks and situations and is the dominant type of blended learning. Self-efficacy determines the content and essence of learners' inner imagination about future learning scenes or procedures, and directly or indirectly affects individual psychological momentum while performing learning activities, thereby generating an impact on real-life learning activities and forming strong associations with learning performance (Bandura and Watts, 1995; Chamorro-Premuzic et al., 2010; Schneider and Preckel, 2017).

\section{Learning Motivation}

According to Ford (1992), learning motivation is defined as a psychological mode in pursuit of goals, beliefs, and emotions. Motivation refers to something that encourages, instructs, and maintains behaviors, approving of students' devotion to a given direction and persistence in it (Fredricks et al., 2004; Reeves, 2006).

Learning motivation is a key factor influencing learning performance. It is not only a decisive factor in learning performance. Actually, it corresponds to a matched motivation in every task to be accomplished (Weiner, 1990). There are two types of learning motivation, namely extrinsic learning motivation and intrinsic learning motivation. In particular, intrinsic motivation is the dominant type of student learning in blended learning, which implies that students motivated by intrinsic motivation have better task accomplishment learning performance than those motivated by extrinsic motivation (Lin et al., 2003). Numerous studies emphasize the importance of motivation, given its effect on learning performance (Law et al., 2010; Law and Breznik, 2017; Law and Geng, 2018).

\section{Community of Inquiry}

Community of inquiry is widely considered as a model on how members in a society acquire knowledge and solve problems (Garrison et al., 2000). Its core lies in the education experience influenced by the interaction between social, cognitive, and teaching presence. These three types of presence are paramount to the education-oriented COI and can improve or constrain education experience and learning outcomes (Garrison et al., 2000). The framework is shown in Figure 1.

\section{Cognitive Presence}

Cognitive presence is the student's ability to construct meanings through discussion and reflection in COI, which demonstrates 


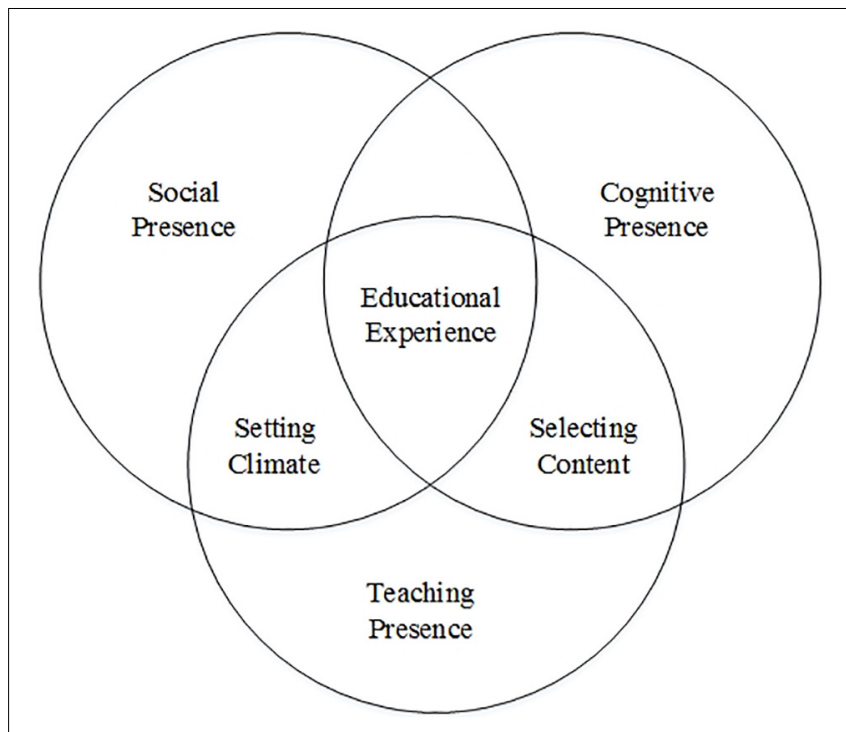

FIGURE 1 | The community of inquiry (Law et al., 2019).

the process of learning and investigation (Garrison, 2011). It entails trigger events, exploration, integration, and reflection, as well as the resolution of learning problems. In the triggering stage, learning tasks can be generated based on doubts about certain knowledge so that students can be prompted into exploration. In the second stage, students can exchange information and engage in critical thinking and investigation in the learning community. In the integration stage, students construct meanings based on the reflection and thoughts from the exploration stage. Finally, students solve their problems in the learning tasks by directly or indirectly using the meanings constructed from the last stage. For the formation of cognitive presence, COI provides an enabling environment to establish and confirm meanings through constant reflection and critical discourse (Garrison et al., 2000).

\section{Social Presence}

Social presence means the ability for individual students to get in touch with the community, conduct meaningful communication in a trustworthy environment, and develop interpersonal relationships by demonstrating individual characteristics (Garrison, 2011). To achieve social presence, the model must afford an open communication environment that is useful in fabricating the favorable relationship between team cohesiveness and individuals. Students may express their thoughts and emotions with a communication method popular in the community (Garrison et al., 2000). Social presence presents a sense of belonging and also a mechanism of free expression to students and sustains team cohesiveness. As a supporting function of cognitive presence, it indirectly promotes the critical thinking process of learners in the community.

\section{Teaching Presence}

Teaching presence is defined as "the design, facilitation, and direction of cognitive and social processes for the purpose of realizing personally meaningful and educationally worthwhile learning outcomes" (p.3) (Anderson et al., 2001). Teaching design involves designing courses and teaching methods and organizing relevant discussions. Facilitation means to create a learning environment that encourages people to share their personal views for effective communication. Direction is to collectively discuss and resolve problems. In essence, teaching presence is the atmosphere of teaching that combines social and cognitive presence effectively and efficiently (Garrison, 2011).

\section{RESEARCH HYPOTHESES}

\section{Perceived Precision Teaching, Self-Efficacy, and Learning Motivation}

There are four steps in precision teaching, including deciding targeted learning goals, recording learning processes, teaching with purpose, and re-examining the attainment of goals (Pinpoint, Record, Change, and Try Again) (Kubina and Yurich, 2012). In an environment of blended learning featuring precision teaching, learners can perceive that there are clear goals in their study, relevant learning materials, and lectures targeting learning problems. Such perceptions can raise the expectation of success in attaining the learning goals, which is likely to ignite learning motivation (Gorges and Kandler, 2012; Cho et al., 2019). When learners clearly perceive the goals to attain and preview the lectures on their own with the online learning system, they tend to be more oriented and purposeful in their studies, so that their self-efficacy is improved to complete learning tasks according to their goals (Law et al., 2010). When they finish previewing the lectures, they proceed to self-testing to see if the goals are attained, which conveniently indicates to the learners the goals achieved and those yet to be achieved. Checking off the goals can motivate the learners and inform them of the unattained goals, which facilitates intentional planning for the next steps and increases self-efficacy for goal attainment (Hong and Park, 2012; Doumen et al., 2014). During lectures, teachers organize teaching and discussion around the problems that have occurred in the learners' learning process, so that students can perceive "the lectures are exactly about what they themselves do not quite understand," thus adding to the motivation to invest more efforts into learning (Rebecca and Michelle, 2016). After the lectures, teachers provide tests based on the feedback during lectures and the learning goals. This way, after self-review, in-class learning, and self-testing post-class, students have a better understanding of the content and hence increased learning motivation (Roberts and Norwich, 2010; Rebecca and Michelle, 2016). Therefore, we put forward the following hypotheses:

H1. PPT is positively related to self-efficacy.

$\mathrm{H} 2$. PPT is positively related to learning motivation.

\section{Self-Efficacy and COI}

Self-efficacy directly affects individuals' dynamic psychological processes in the learning performance of specific activities (Wood and Bandura, 1989), decides their behavioral choices, and forces them to prefer the environment or activity that they feel they 
are most competent in. It may also affect their efforts, meaning that individuals put in more energy as long as they maintain high self-efficacy over an assignment (Paglis and Green, 2010).

In a blended learning environment with precision teaching, teachers outline precise goals and requirements. In this case, students with high self-efficacy actively contact the teachers, discuss with their classmates, and finish the tasks as required. The higher the self-efficacy, the more active the students would be in sharing knowledge and engaging in discussions (Hsu et al., 2007), and thereby, the stronger would be the social presence that they experience. In the process, those with higher self-efficacy tend to make more efforts in learning and have a better perception of the carefully crafted atmosphere for teaching, that is, a better perception of teaching presence (Akyol and Garrison, 2011). In precision teaching, students preview the content and finish self-testing according to their goals before the lectures. During the lectures, teachers organize teaching and discussion based on the problems that have occurred in the self-learning and selftesting, and further test if the goals are achieved after the lectures. Students with higher self-efficacy can immerse better into the entire learning process (Christina, 2000; Park et al., 2012), which would increase the cognitive presence of learners (Celikkaleli, 2014; Niemiec and Lachowicz-Tabaczek, 2015). To examine the influence of self-efficacy in the blended learning environment, the following hypotheses are proposed:

H3. Self-efficacy is positively related to COI.

$\mathrm{H} 3 \mathrm{a}$. Self-efficacy is positively related to cognitive presence.

$\mathrm{H} 3 \mathrm{~b}$. Self-efficacy is positively related to social presence.

$\mathrm{H} 3 \mathrm{c}$. Self-efficacy is positively related to teaching presence.

\section{Learning Motivation and COI}

Motivation embodies the in-depth intention of every learner for a direction or goal. Bandura (1996) considers that people commit to their work or task out of personal belief, and learners' belief in ability usually better reflects motivation than their actual ability. Corresponding to a group of physiological processes, motivation may determine behavioral direction and persistence (Moos and Marroquin, 2010). If a student wants to improve or develop their own ability in a given task or discipline, they usually seek pertinent help or reflects repeatedly.

Although blended learning courses offer flexible and convenient online learning content, students may lack the motivation to complete the tasks (Bennett et al., 2012; TorrisiSteele and Drew, 2013), and suffer from procrastination (Cerezo et al., 2017). Motivated students have a strong connection with their teachers and endeavor to establish social relations with their peers (Patrick et al., 2007; Wentzel et al., 2010; Law and Geng, 2018). Such quality would improve the social presence in learning. By actively engaging in online and classroom learning, these students can effectively become accustomed to a digitalized learning environment and cope with learning problems, resulting in a better teaching presence (Zimmergembeck and Locke, 2007; Manganelli et al., 2019). Highly motivated students may make full use of the advantages of precision teaching to learn and explore, and eventually experience a better cognitive presence (Manganelli et al., 2019). The following hypotheses are thus presented:

H4. Learning motivation is positively related to COI.

H4a. Learning motivation is positively related to cognitive presence.

H4b. Learning motivation is positively related to social presence.

H4c. Learning motivation is positively related to teaching presence.

\section{COI and Learning Performance}

In a COI course, students take more personal responsibilities and share multiple viewpoints more actively. Through vigorous online interaction, students and teachers together can create a COI environment with social, cognitive, and teaching presence (Akyol et al., 2011; Kozan and Richardson, 2014). This implies that extensive participation of teachers and their clarity in course design would affect students' perceived learning (Swan, 2001). In some teaching and learning environments, in an engineering course, for instance, teachers' performance plays a decisive role in learning performance, outweighing social and cognitive presence in importance (Szeto, 2015). Students' involvement in discussions, their motivation, and cooperation with others can influence their learning and performance (Chong, 1998; Swan, 2001; Davies and Graff, 2005). In the research on the effects of cohesion and interaction on team performance among students, social presence is closely related to learning outcomes (Arbaugh, 2005; Williams et al., 2006). The COI framework suggests an approach to creating collaboration and meaningful learning experiences, which can improve or undermine education experiences and learning outcomes (Garrison et al., 2000). Three types of presence are thus predictive of learning performance (Arbaugh, 2008; Choy and Quek, 2016). Hence, we propose the following hypotheses:

H5. COI is positively related to learning performance.

H5a. Cognitive presence is positively related to learning performance.

H5b. Social presence is positively related to learning performance.

H5c. Teaching presence is positively related to learning performance.

Based on the above analysis, the constructed model composed of previous hypotheses is developed, as shown in Figure 2.

\section{MATERIALS AND METHODS}

\section{Measurement}

We conducted a questionnaire survey to test the above five sets of hypotheses. The questionnaire is adapted from mature scales in the relevant literature and presented in Chinese. We invited a professor of English to translate the scales originally in English into Chinese and another professor of English to check if the translation was appropriate. Then, six students who participated in the course attentively were asked to fill in the 


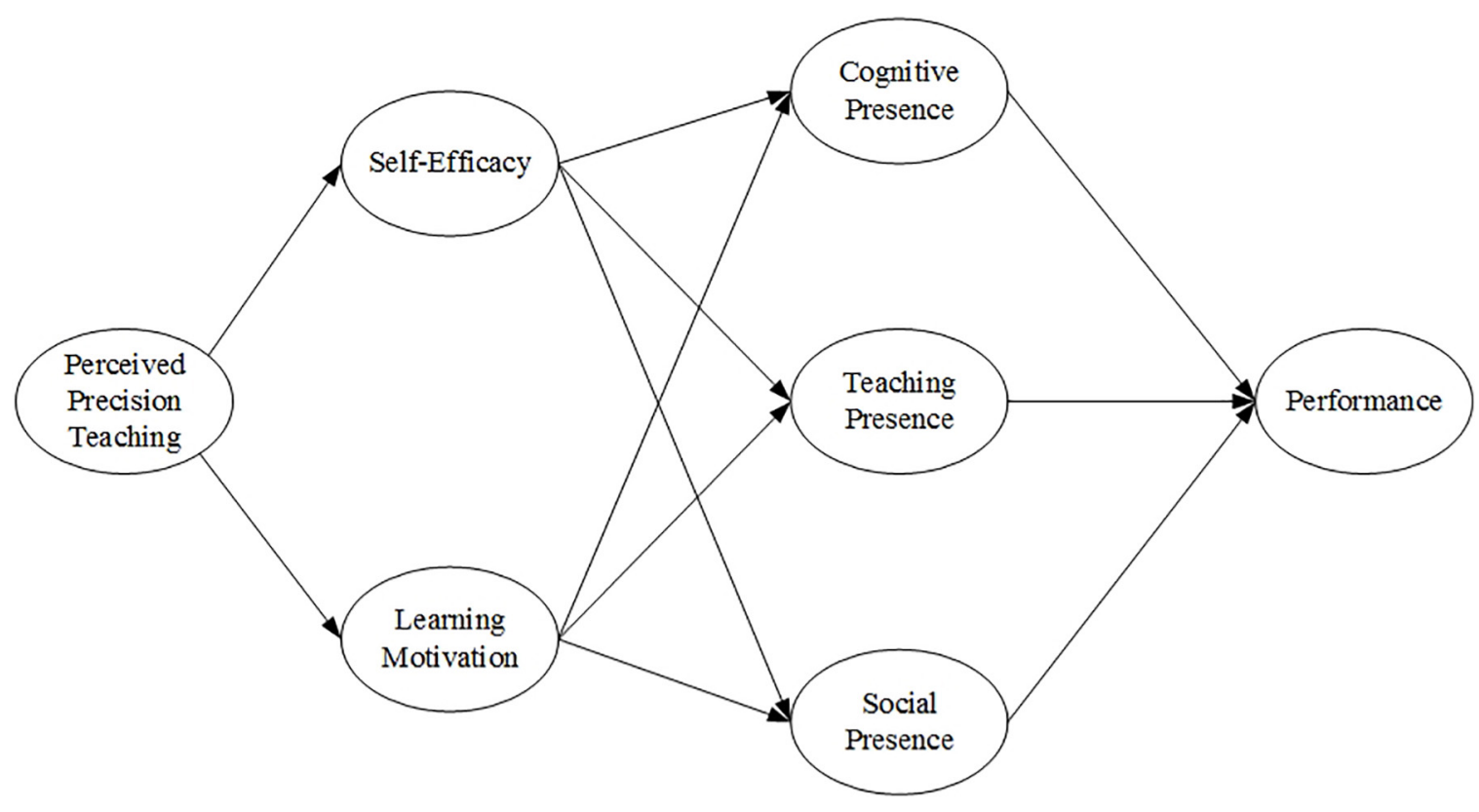

FIGURE 2 | Research model.

questionnaire and inform the researchers of how they understood the questionnaire. In view of the students' feedback, the two English professors improved the Chinese translation. This was to ensure consistency in content between the Chinese and English scales, as well as the accuracy in the respondents' understanding. The questionnaire encompasses PPT, self-efficacy (SE), learning motivation (LM), teaching presence (TP), social presence (SP), cognitive presence (CP), and learning performance (PERF). The items and references are detailed in Appendix A. The questionnaire adopted a five-point Likert scale [from "strongly disagree" (1) to "strongly agree" (5)] and the respondents were required to complete the survey anonymously.

\section{Experiment Setting and Participants}

To test the research model, we provided a blended learning course of "Computer Network Technologies" featuring precision teaching for one term in a university in a large city in China. The participants of our study were 258 students majoring in e-commerce. The learning process is depicted in Figure 3, which was integrated into a blended learning process the four basic steps of precision teaching, that is, pinpoint, record, change, and try again (Benbunan-Fich, 2008; Kubina and Yurich, 2012). At the end of the term, the abovementioned questionnaire (See Appendix A) was distributed to the participants. Of the 258 students who completed the survey, 256 valid questionnaires remained after the removal of two incomplete ones.

The general information of the respondents is as shown below (Table 1). It can be easily seen that there are more female students than male students, primarily because e-commerce is a management specialty under liberal arts of the school. Most of these students are aged $20-22$ years.

\section{Hypothesis Verification}

The model (Figure 2) is verified with the partial least squares (PLS) approach of SEM. PLS here refers to an alternative least squares algorithm that expands principal component analysis and typical correlation analysis (Henseler and Sarstedt, 2013). It is composed of two sets of equations that are called the inner model and the outer model, respectively. Among them, the inner model defines the relationship between unobserved variables or latent variables, and the outer counterpart defines the relationship between latent variables and observed indicators. PLS-SEM can predict a relatively complicated model with no need to meet the distribution hypothesis, and for this reason, it is applicable to the handling of non-normal distribution data. This phenomenon is commonplace for business and social science researchers (Fornell and Bookstein, 1982; Hair et al., 2014b; Sarstedt et al., 2014). Accordingly, PLS methods in SmartPLS software are adopted here.

\section{RESULTS}

Analysis and explanation for the PLS model was carried out in two stages: (1) assessment of the measurement model's reliability and validity and (2) assessment of the structural model.

\section{Assessment of the Measurement Model}

To ensure the fine reliability and validity of the research, a test is conducted to examine the seven dimensions of the structure, including PPT, self-efficacy, learning motivation, social presence, cognitive presence, teaching presence, and learning performance. For each item, the factor loading is above 0.7 (Table 2). Structural convergence validity is assessed in accordance with the estimation 


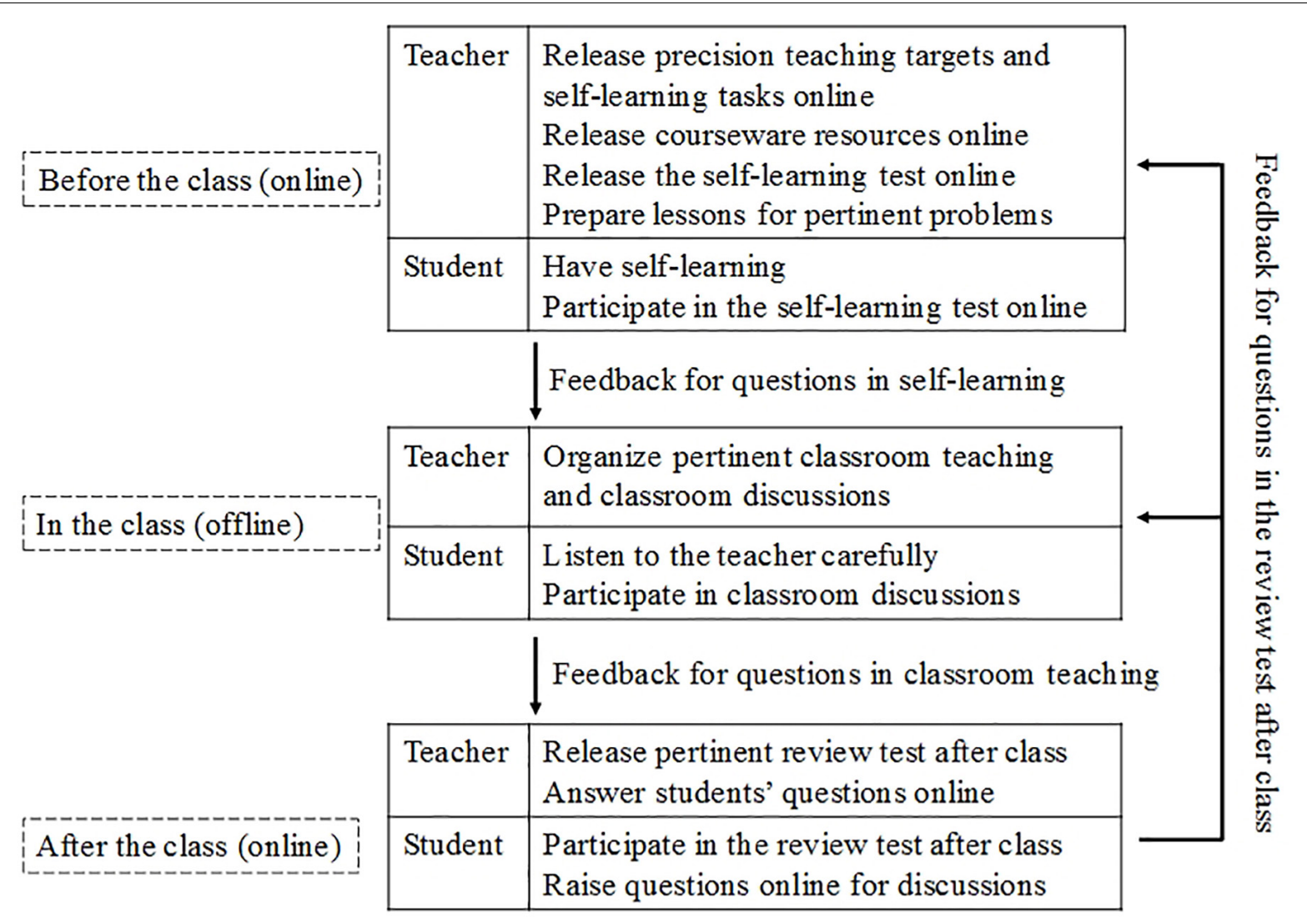

FIGURE 3 | Blended learning process featuring precision teaching

results of the measurement model. Reflective measurement is considered reliable when the item's factor loading over the correlation factor is high (above 0.7) (Fornell and Larcker, 1981). Subsequently, Cronbach's alpha, Dillon-Goldstein's rho, composite reliability, and average variance extracted (AVE) are used to test construct reliability and validity (Table 3). For all constructs, Cronbach's alpha and Dillon-Goldstein's rho are greater than 0.7 , congruent with the acceptable criterion (Nunnally, 1968), and composite reliability is greater than 0.9, far above the recommended value of 0.5 (Chin and Gopal, 1995). Additionally, the AVE value greater than the minimum 0.5 well proves the reliability and validity of the research (Fornell and Larcker, 1981). These indicators demonstrate the feasibility of all constructs for follow-up research.

The discriminant validity of the constructs is assessed based on the Fornell and Larcker (1981) criterion. According to Fornell and Larcker (1981), for good discriminant validity, the square root of the AVE of the constructs should be larger than the correlation coefficient between the constructs. All the constructs in the estimated model are in line with this criterion (Fornell and Larcker, 1981; See Table 4).

\section{Assessment of the Structural Model}

Surveyed data executed 5,000 bootstrapping procedure model operations using SmartPLS3. Figure 4 presents the results of
TABLE 1 | Demographic characteristics of students interviewed.

\begin{tabular}{lccc}
\hline Indicator & Indicator value & Count & Percentage \\
\hline Gender & Male & 101 & $39.45 \%$ \\
Age group & Female & 155 & $60.55 \%$ \\
& Below 18 & 0 & $0.00 \%$ \\
& $18-19$ & 5 & $1.95 \%$ \\
& $20-21$ & 100 & $39.06 \%$ \\
Total & $22-23$ & 145 & $56.64 \%$ \\
& Above 23 & 6 & $2.34 \%$ \\
\end{tabular}

the hypothesis verification vividly. The direct and indirect effects of the seven constructs are tested, and the results are as shown in Tables 5, 6 .

In blended learning, PPT is positively and directly related to self-efficacy $(\beta=0.699, p<0.001)$, and learning motivation $(\beta=0.727, p<0.001)$, supporting the validity of $\mathrm{H} 1$ and $\mathrm{H} 2$. PPT is positively and indirectly related to cognitive presence $(\beta=0.658, p<0.001)$, teaching presence $(\beta=0.589, p<0.001)$, and social presence $(\beta=0.633, p<0.001)$, and eventually learning performance $(\beta=0.573, p<0.001)$; and self-efficacy is positively and directly related to cognitive presence $(\beta=0.456$, $p<0.001)$, teaching presence $(\beta=0.224, p=0.001)$, and social 
TABLE 2 | Outer model estimation.

\begin{tabular}{|c|c|c|c|}
\hline Latent variable & $\begin{array}{l}\text { Manifest } \\
\text { variables }\end{array}$ & $\begin{array}{l}\text { Factor } \\
\text { Loadings }\end{array}$ & Outer Weights \\
\hline \multirow{4}{*}{$\begin{array}{l}\text { Perceived Precision Teaching } \\
\text { (PPT) }\end{array}$} & PPT_1 & 0.918 & 0.272 \\
\hline & PPT_2 & 0.914 & 0.272 \\
\hline & PPT_3 & 0.926 & 0.272 \\
\hline & PPT_4 & 0.919 & 0.272 \\
\hline \multirow[t]{7}{*}{ Self-Efficacy (SE) } & SE_1 & 0.814 & 0.165 \\
\hline & SE_2 & 0.857 & 0.183 \\
\hline & SE_3 & 0.858 & 0.176 \\
\hline & SE_4 & 0.860 & 0.169 \\
\hline & SE_5 & 0.839 & 0.184 \\
\hline & SE_6 & 0.843 & 0.175 \\
\hline & SE_7 & 0.741 & 0.149 \\
\hline \multirow[t]{5}{*}{ Learning Motivation (LM) } & LM_1 & 0.880 & 0.215 \\
\hline & LM_2 & 0.905 & 0.226 \\
\hline & LM_3 & 0.881 & 0.220 \\
\hline & LM_4 & 0.913 & 0.222 \\
\hline & LM_5 & 0.914 & 0.228 \\
\hline \multirow[t]{7}{*}{ Cognitive Presence (CP) } & $\mathrm{CP}_{-} 1$ & 0.854 & 0.170 \\
\hline & CP_2 & 0.847 & 0.170 \\
\hline & CP_3 & 0.834 & 0.149 \\
\hline & $\mathrm{CP}_{-} 4$ & 0.861 & 0.169 \\
\hline & CP_5 & 0.861 & 0.165 \\
\hline & CP_6 & 0.882 & 0.167 \\
\hline & $\mathrm{CP}_{-} 7$ & 0.882 & 0.172 \\
\hline \multirow[t]{6}{*}{ Social Presence (SP) } & SP_1 & 0.886 & 0.183 \\
\hline & SP_2 & 0.882 & 0.177 \\
\hline & SP_3 & 0.875 & 0.183 \\
\hline & $\mathrm{SP}_{-} 4$ & 0.910 & 0.193 \\
\hline & SP_5 & 0.892 & 0.191 \\
\hline & SP_6 & 0.895 & 0.196 \\
\hline \multirow[t]{4}{*}{ Teaching Presence (TP) } & TP_1 & 0.919 & 0.277 \\
\hline & TP_2 & 0.908 & 0.258 \\
\hline & TP_3 & 0.919 & 0.272 \\
\hline & TP_4 & 0.911 & 0.287 \\
\hline \multirow[t]{3}{*}{ Preference (PREF) } & PER_1 & 0.944 & 0.352 \\
\hline & PER_2 & 0.942 & 0.348 \\
\hline & PER_3 & 0.949 & 0.357 \\
\hline
\end{tabular}

TABLE 3 | Construct reliability and validity.

\begin{tabular}{lccccc}
\hline & MVs & $\begin{array}{c}\text { Cronbach's } \\
\text { Alpha }\end{array}$ & Rho_A & $\begin{array}{c}\text { Composite } \\
\text { Reliability }\end{array}$ & AVE \\
\hline PPT & 4 & 0.939 & 0.939 & 0.956 & 0.845 \\
SE & 7 & 0.925 & 0.928 & 0.940 & 0.691 \\
LM & 5 & 0.940 & 0.941 & 0.955 & 0.808 \\
CP & 7 & 0.941 & 0.942 & 0.952 & 0.740 \\
TP & 4 & 0.935 & 0.936 & 0.953 & 0.836 \\
SP & 5 & 0.947 & 0.948 & 0.958 & 0.792 \\
PER & 3 & 0.940 & 0.940 & 0.962 & 0.893
\end{tabular}

presence $(\beta=0.367, p<0.001)$, supporting the validity of $\mathrm{H} 3 \mathrm{a}, \mathrm{H} 3 \mathrm{~b}$, and $\mathrm{H} 3 \mathrm{c}$, respectively, and therefore attesting that $\mathrm{H} 3$ is tenable. Learning motivation is positively and directly
TABLE 4 | Fornell and Larcker (1981) criterion.

\begin{tabular}{lccccccc}
\hline & PPT & SE & LM & CP & TP & SP & PER \\
\hline PPT & $\mathbf{0 . 9 1 9}$ & & & & & & \\
SE & 0.699 & $\mathbf{0 . 8 3 1}$ & & & & & \\
LM & 0.727 & 0.767 & $\mathbf{0 . 8 9 9}$ & & & & \\
CP & 0.664 & 0.813 & 0.816 & $\mathbf{0 . 8 6 0}$ & & & \\
TP & 0.734 & 0.679 & 0.766 & 0.778 & $\mathbf{0 . 9 1 4}$ & & \\
SP & 0.688 & 0.764 & 0.799 & 0.837 & 0.813 & $\mathbf{0 . 8 9 0}$ & \\
PER & 0.695 & 0.747 & 0.774 & 0.796 & 0.807 & 0.802 & $\mathbf{0 . 9 4 5}$
\end{tabular}

The square root of the average variance extracted (AVE) for each construct is denoted in bold and italic, while the inter-construct correlations are shown offdiagonally.

related to cognitive presence $(\beta=0.466, p<0.001)$, teaching presence $(\beta=0.594, p<0.001)$, and social presence $(\beta=0.517$, $p<0.001$ ), supporting the validity of $\mathrm{H} 4 \mathrm{a}, \mathrm{H} 4 \mathrm{~b}$, and $\mathrm{H} 4 \mathrm{c}$, respectively, and therefore attesting that $\mathrm{H} 4$ is tenable. Cognitive presence is positively and directly related to learning performance $(\beta=0.295, p<0.001)$, teaching presence is positively and directly related to learning performance $(\beta=0.372, p<0.001)$, and social presence is positively and directly related to learning performance $(\beta=0.253, p=0.006)$, supporting the validity of $\mathrm{H} 5 \mathrm{a}, \mathrm{H} 5 \mathrm{~b}$, and $\mathrm{H} 5 \mathrm{c}$, respectively and therefore attesting that $\mathrm{H} 5$ is tenable.

As PLS path modeling cannot provide a widely accepted global model fitting (Hair et al., 2017b), the research deliberately adopts standardized root mean square residual (SRMR) for model fitting, finding that model SRMR value of 0.042 below 0.08 is acceptable (Hair et al., 2017b).

\section{Predictive Relevance and Effect Size}

In addition to the use of determining the coefficient $\left(\mathrm{R}^{2}\right)$ in assessing the model's predictive accuracy, cross-validation redundancy $\left(\mathrm{Q}^{2}\right)$ may be also used to determine the predictive relevance of the model (Hair et al., 2014a). The model possesses predictive relevance in the case that the endogenous variable value $\mathrm{Q}^{2}$ is greater than 0 (Hair et al., 2017a). Table 7 also suggests that the model has predictive relevance in self-efficacy, learning motivation, cognitive presence, teaching presence, social presence, and learning performance.

Additionally, Table 7 calculates the effect size of each exogenous variable $f^{2}$. According to Hair et al. (2014a), effect size $\mathrm{f}^{2}$ indicates the contribution of the exogenous variable to the endogenous variable $\mathrm{R}^{2}$, and $0.02,0.15$, and 0.35 suggesting small, medium, and large effects, respectively (Hair et al., 2014a,b). PPT has a large effect on self-efficacy (SE) $\left(f^{2}=0.957\right)$ and learning motivation $(\mathrm{LM})\left(f^{2}=1.123\right)$; selfefficacy (SE) has a large effect on cognitive presence (CP) $\left(f^{2}=0.344\right)$, a small effect on teaching presence (TP) $\left(f^{2}=0.053\right)$, and a medium effect on social presence (SP) $\left(f^{2}=0.182\right)$; learning motivation has a large effect on cognitive presence (CP) $\left(f^{2}=0.360\right)$, teaching presence (TP) $\left(f^{2}=0.370\right)$, and social presence $(\mathrm{SP})\left(f^{2}=0.359\right)$; cognitive presence $(\mathrm{CP})$ and social presence (SP) have a small effect on learning performance (PER) $\left(f^{2}=0.090, f^{2}=0.057\right)$; and teaching 


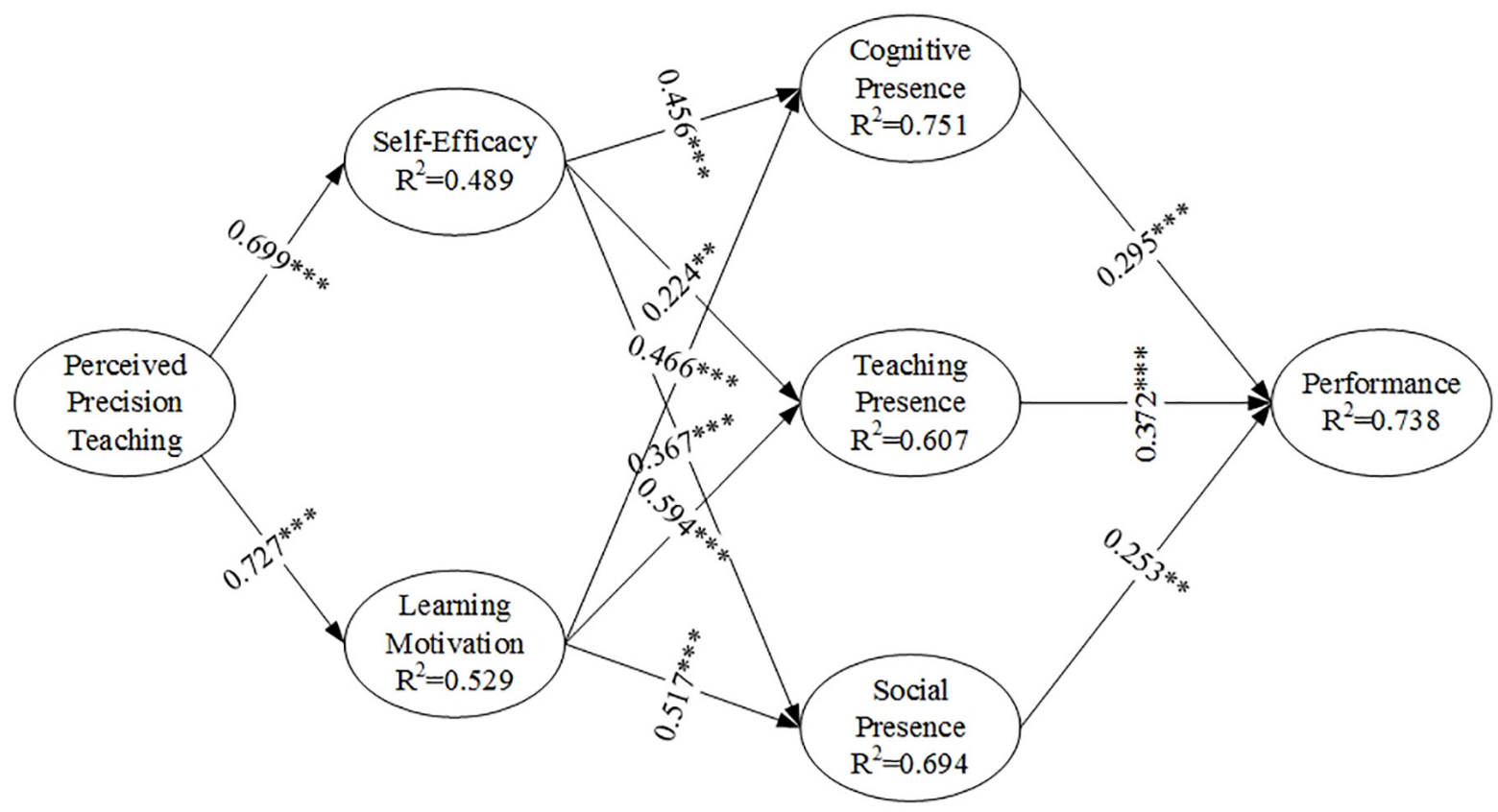

$* * * p<0.001, * * p<0.010$ (two-tailed t-test)

FIGURE 4 | PLS structural model.

TABLE 5 | Structural model path coefficient (1).

\begin{tabular}{|c|c|c|c|c|c|c|}
\hline & \multicolumn{2}{|c|}{ SE } & \multicolumn{2}{|c|}{ LM } & \multicolumn{2}{|c|}{ CP } \\
\hline & Direct & Indirect & Direct & Indirect & Direct & Indirect \\
\hline PPT & $0.699^{\star \star \star}$ & & $0.727^{\star \star \star}$ & & & $0.658^{\star \star \star}$ \\
\hline SE & & & & & $0.456^{\star \star \star}$ & \\
\hline LM & & & & & $0.466^{\star \star \star}$ & \\
\hline \multicolumn{7}{|l|}{$\mathrm{CP}$} \\
\hline \multicolumn{7}{|l|}{ TP } \\
\hline SP & & & & & & \\
\hline
\end{tabular}

presence has a medium effect on learning performance (PER) $\left(f^{2}=0.162\right)$.

\section{DISCUSSION}

By analyzing 256 students from a blended learning environment featuring precision teaching at the end of the term, this study sheds light on the relationship between PPT and learning performance in a blended learning environment. Specifically, PPT positively correlates with self-efficacy and learning motivation, while self-efficacy, learning motivation, and COI exerts a serial mediating effect on the relations between PPT and learning performance.
TABLE 6 | Structural model path coefficient (2).

\begin{tabular}{|c|c|c|c|c|c|c|}
\hline & \multicolumn{2}{|c|}{ TP } & \multicolumn{2}{|c|}{ SP } & \multicolumn{2}{|c|}{ PER } \\
\hline & Direct & Indirect & Direct & Indirect & Direct & Indirect \\
\hline PPT & & $0.589^{\star \star \star}$ & & $0.633^{\star \star \star}$ & & $0.573^{\star \star \star}$ \\
\hline SE & $0.224^{\star \star}$ & & $0.367^{\star \star \star}$ & & & $0.311^{\star \star \star}$ \\
\hline LM & $0.594^{\star \star \star}$ & & $0.517^{\star \star \star}$ & & & $0.489^{\star \star \star}$ \\
\hline $\mathrm{CP}$ & & & & & $0.295^{\star \star \star}$ & \\
\hline TP & & & & & $0.372^{\star \star \star}$ & \\
\hline SP & & & & & $0.253^{\star *}$ & \\
\hline
\end{tabular}

${ }^{* * *} p<0.001,{ }^{* *} p<0.010$ (two-tailed $t$-test).

TABLE 7 | Predictive relevance and effect size.

\begin{tabular}{|c|c|c|c|c|}
\hline & $\mathbf{R}^{2}$ & $\mathbf{Q}^{2}$ & Exogenous variables & Effect size $f^{2}$ \\
\hline SE & 0.489 & 0.333 & PPT & 0.957 \\
\hline LM & 0.529 & 0.425 & PPT & 1.123 \\
\hline \multirow[t]{2}{*}{$\mathrm{CP}$} & 0.751 & 0.551 & SE & 0.344 \\
\hline & & & LM & 0.360 \\
\hline \multirow[t]{2}{*}{ TP } & 0.607 & 0.501 & SE & 0.053 \\
\hline & & & LM & 0.370 \\
\hline \multirow[t]{2}{*}{ SP } & 0.694 & 0.543 & SE & 0.182 \\
\hline & & & LM & 0.359 \\
\hline \multirow[t]{3}{*}{ PER } & 0.738 & 0.650 & $\mathrm{CP}$ & 0.090 \\
\hline & & & TP & 0.162 \\
\hline & & & SP & 0.057 \\
\hline
\end{tabular}




\section{Perceived Precision Teaching, Self-Efficacy, and Learning Motivation}

In this research, we find that PPT is positively related to self-efficacy and learning motivation, with great predictive relevance and effect. It is also indirectly and positively related to learning performance. In a blended learning experience featuring precision teaching, students are requested to learn the online course content by themselves before class and join in the test. Students' test scores are recorded by the system. In this way, students have already made sufficient preparations and show greater selfefficacy in classroom teaching beforehand. On the part of teachers, they can have pertinent and well-organized teaching interventions for problems discovered in the testing procedure (Kubina and Yurich, 2012). Facts prove that more pertinent teaching easily attracts students' attention, arouses their interests, and stimulates their self-efficacy and learning motivation.

\section{Self-Efficacy, Cognitive Presence, Social Presence, Teaching Presence, and Learning Performance}

The research reveals that self-efficacy is directly and positively related to cognitive presence, social presence, and teaching presence, with varying predictive relevance and effect size, and is indirectly and positively related to learning performance. In blended learning environments featuring precision teaching, students are asked to preview and join in the test before class, so that they can basically grasp the course content, reinforce self-efficacy, and the willingness to have exchanges with classmates and teachers, and more easily get immersed in the teaching process. These behaviors are all directly and positively related to their learning performance.

\section{Learning Motivation, Cognitive Presence, Social Presence, Teaching Presence, and Learning Performance}

Learning motivation is a key factor for active learning and also a decisive factor for student learning performance and expression (Weiner, 1990; Law et al., 2010; Law and Breznik, 2017; Law and Geng, 2018). Learning motivation may be stimulated by endogenous and exogenous factors, in which endogenous learning motivation is the dominant type in blended learning courses (Lin et al., 2003). Simultaneously, it has been found that learning motivation is directly and positively related to cognitive presence, social presence, and teaching presence, with great predictive relevance and effect, and indirectly and positively related to learning performance. Those students who have strong learning motivation are also inclined to more positively participate in course assignments and group activities. From this perspective, learning motivation promotes learning performance via its positive and direct relation to social presence and teaching presence.

\section{Serial Mediating Effect of Perceived Precision Teaching on Learning Performance}

In this study, it is observed that self-efficacy, learning motivation, and COI (including cognitive presence, teaching presence, and social presence) generate a serial mediating effect between PPT and learning performance, that is, PPT improves learners' self-efficacy and learning motivation (Chapman et al., 2005; Roberts and Norwich, 2010; Rebecca and Michelle, 2016), while self-efficacy and learning motivation are directly related to COI, and COI is positively related to learning performance (Akyol and Garrison, 2011; Akyol et al., 2011; Kozan and Richardson, 2014).

\section{CONCLUSION}

This study discusses and verifies the relation between PPT and learning performance in blended learning environments, that is, PPT is positively related to self-efficacy and learning motivation, self-efficacy and learning motivation are positively related to COI (including cognitive presence, teaching presence and social presence), COI is positively related to learning performance, and PPT remotely and positively predicts learning performance.

Throughout the whole process, PPT is not only the starting point but also the most critical link which eventually predicts learning performance. As for the design for blended learning courses featuring precision teaching, the first step is to pinpoint by setting up test questions to check the achievements of learning goals, so that students clearly know their learning goals before participating in online learning, experience pertinent learning, and finally, examine the achievements of learning goals after learning. The second step is record, which illustrates that the online learning system can elaborately record students' achievements of the learning process, and reflects their problems encountered in the learning process timely and precisely. The third step is change; herein, teachers are expected to precisely grasp the learning conditions and problems via the online learning system before class, prepare lessons based on the data analysis (Bruhn et al., 2020), organize pertinent discussions and classroom teaching during class, and thus ensure that the taught knowledge points exactly to solve what may be puzzling the students. The last step is try again. After class, students must have proper tests in online learning systems to check if their personal learning goals have been achieved yet, and if not, efforts should be made further by the teachers to improve the blended learning effects through pertinent teaching preparations. If precision teaching works, students familiarize themselves with the learning content before class, which in turn, boosts students' confidence, obviously enhancing their self-efficacy and learning motivation, and motivating them to participate in course learning and class discussions. Pertinent teaching in class further reinforces students' interests in learning and eventually has a 
positive impact on learning performance. A good understanding of the flow, content design, and effective implementation of precision teaching is therefore meaningful for obtaining favorable learning performance.

The theoretical significance of this study is that it manifests the relation between PPT in blended learning and learning performance through self-efficacy, learning motivation, and COI, and provides new insight into research on blended learning performance. The meaning of teaching practice is to offer a realistic reference to the development of precision teaching practice in a blended learning environment and present an effective way to improve learning performance. Accompanied by the fast advance of information technology and the sustained growth of teacher-student information attainments, blended learning gains an increasingly wide scope of application, and meanwhile, more and more technical systems create many conveniences to the implementation of precision teaching. It is foreseeable that precision teaching will be applied in various teaching practices in the future.

\section{RESEARCH LIMITATIONS AND SUGGESTIONS FOR FURTHER STUDY}

Due to the limitation of the course for blended learning featuring precision teaching, our participants are mainly from the same course. It is expected that future research could expand to more blended courses with precision teaching. However, the results are based on an analysis of Chinese students, so the generalizability to students in other countries is yet to be confirmed.

\section{REFERENCES}

Afacan, Y. (2016). Exploring the effectiveness of blended learning in interior design education. Innov. Educ. Teach. Int. 53, 508-518. doi: 10.1080/14703297.2015. 1015595

Akyol, Z., and Garrison, D. R. (2011). Assessing metacognition in an online community of inquiry. Internet High. Educ. 14, 183-190. doi: 10.1016/j.iheduc. 2011.01.005

Akyol, Z., Vaughan, N., and Garrison, D. R. (2011). The impact of course duration on the development of a community of inquiry. Interact. Learn. Environ. 19, 231-246. doi: 10.1080/10494820902809147

Alammary, A. (2019). Blended learning models for introductory programming courses: a systematic review. PLoS One 14:e0221765. doi: 10.1371/journal.pone. 0221765

Alammary, A., Sheard, J., and Carbone, A. (2014). Blended learning in higher education: three different design approaches. Australas. J. Educ. Technol. 30, 440-454.

Anderson, T., Rourke, L., Garrison, D. R., and Archer, W. (2001). Assessing teaching presence in a computer conferencing context. Online Learn. 5, 1-17.

Arbaugh, J. B. (2005). Is there an optimal design for on-line MBA courses? Acad. Manag. Learn. Educ. 4, 135-149. doi: 10.5465/amle.2005.172 68561

Arbaugh, J. B. (2008). Does the community of inquiry framework predict outcomes in online MBA courses? Int. Rev. Res. Open Distance Learn. 9, 1-21. doi: 10.5465/ambpp.2007.26508387

Artino, A. R., and Mccoach, D. B. (2008). Development and initial validation of the online learning value and self-efficacy scale. J. Educ. Comput. Res. 38, 279-303. doi: 10.2190/EC.38.3.c

\section{DATA AVAILABILITY STATEMENT}

The raw data supporting the conclusions of this article will be made available by the authors, without undue reservation.

\section{ETHICS STATEMENT}

Ethical review and approval was not required for the study on human participants in accordance with the local legislation and institutional requirements. Written informed consent for participation was not required for this study in accordance with the national legislation and the institutional requirements.

\section{AUTHOR CONTRIBUTIONS}

BY: writing-original draft. C-HY: writing-review and editing. Both authors have read and agreed to the published version of the manuscript.

\section{FUNDING}

This project is supported by six research programs in China, including The Teaching Reform Program in Guangdong Education Department (Grant No. S-JY201707), The Guangdong Province Philosophy and Social Science Planning Project (Grant No. GD18XJY01), and University of Electronic Science and Technology of China, Zhongshan Institute (Grant Nos HHKC202013, CG201808, JY202016, and GPY201808).

Bai, Y., Mo, D., Zhang, L. X., Boswell, M., and Rozelle, S. (2016). The impact of integrating ICT with teaching: evidence from a randomized controlled trial in rural schools in China. Comput. Educ. 96, 1-14. doi: 10.1016/j.compedu.2016. 02.005

Bandura, A. (1996). Social Foundations for Thought and Action: A Social Cognitive Theory. Upper Saddle River, NJ: Prentice.

Bandura, A., and Adams, N. E. (1980). Tests of the generality of selfefficacy theory. Cogn. Ther. Res. 4, 39-66. doi: 10.1007/bf01173354

Bandura, A., and Watts, R. E. (1995). Self-Efficacy in Changing Societies. New York, NY: Cambridge University Press.

Benbunan-Fich, R. (2008). Blended learning in higher education: framework, principles, and guidelines. Acad. Manag. Learn. Educ. 7, 135-137.

Bennett, S., Bishop, A., Dalgarno, B., Waycott, J., and Kennedy, G. (2012). Implementing web 2.0 technologies in higher education: a collective case study. Comput. Educ. 59, 524-534. doi: 10.1016/j.compedu.2011.12.022

Blieck, Y., Kauwenberghs, K., Zhu, C., Struyven, K., Pynoo, B., and DePryck, K. (2019). Investigating the relationship between success factors and student participation in online and blended learning in adult education. J. Comput. Assist. Learn. 35, 476-490. doi: 10.1111/jcal.12351

Broadbent, J. (2017). Comparing online and blended learner's self-regulated learning strategies and academic performance. Internet High. Educ. 33, 24-32. doi: 10.1016/j.iheduc.2017.01.004

Bruhn, A. L., Wehby, J. H., and Hasselbring, T. S. (2020). Data-based decision making for social behavior: setting a research agenda. J. Posit. Behav. Interv. 22, 116-126. doi: 10.1177/1098300719876098

Celikkaleli, O. (2014). The relation between cognitive flexibility and academic, social and emotional self-efficacy beliefs among adolescents. Egit. Bilim 39, 347-354. 
Cerezo, R., Esteban, M., Sanchez-Santillan, M., and Nunez, J. C. (2017). Procrastinating behavior in computer-based learning environments to predict performance: a case study in moodle. Front. Psychol. 8:1403. doi: 10.3389/fpsyg. 2017.01403

Chamorro-Premuzic, T., Harlaar, N., Greven, C. U., and Plomin, R. (2010). More than just IQ: a longitudinal examination of self-perceived abilities as predictors of academic performance in a large sample of UK twins. Intelligence 38, 385-392. doi: 10.1016/j.intell.2010.05.002

Chapman, S. S., Ewing, C. B., and Mozzoni, M. P. (2005). Precision teaching and fluency training across cognitive, physical, and academic tasks in children with traumatic brain injury: a multiple baseline study. Behav. Intervent. 20, 37-49. doi: 10.1002/bin.168

Chin, W. W., and Gopal, A. (1995). Adoption intention in GSS: relative importance of beliefs. Data Base Adv. Inf. Syst 26, 42-64. doi: 10.1145/217278.217285

Cho, M. H., Park, S. W., and Lee, S. E. (2019). Student characteristics and learning and teaching factors predicting affective and motivational outcomes in flipped college classrooms. Stud. High. Educ. doi: 10.1080/03075079.2019. 1643303 [Epub ahead of print].

Chong, S. M. (1998). "Models of asynchronous computer conferencing for collaborative learning in large college classes," in Electronic Collaborators: Learner-Centered Technologies for Literacy, Apprenticeship, and Discourse, eds C. J. Bonk and K. S. King (Mahwah, NJ: Lawrence Erlbaum Associates), 157-182.

Choy, J. L. F., and Quek, C. L. (2016). Modelling relationships between students' academic achievement and community of inquiry in an online learning environment for a blended course. Australas. J. Educ. Technol. 32, 106-124.

Christina, K. L. (2000). Computer self-efficacy, academic self-concept and other factors as predictors of satisfaction and future participation of adult learners in Web-based distance education. Diss. Abstr. Int. Sec. A Hum. Soc. Sci. 61:581.

Cocquyt, C., Zhu, C., Diep, A. N., De Greef, M., and Vanwing, T. (2019). Examining the role of learning support in blended learning for adults' social inclusion and social capital. Comput. Educ. 142:103610. doi: 10.1016/j.compedu.2019.10361

Dakduk, S., Santalla-Banderali, Z., and van der Woude, D. (2018). Acceptance of blended learning in executive education. SAGE Open 8:21582440188. doi: $10.1177 / 2158244018800647$

Darling-Aduana, J., and Heinrich, C. J. (2018). The role of teacher capacity and instructional practice in the integration of educational technology for emergent bilingual students. Comput. Educ. 126, 417-432. doi: 10.1016/j.compedu.2018. 08.002

Datchuk, S. M. (2017). A direct instruction and precision teaching intervention to improve the sentence construction of middle school students with writing difficulties. J. Spec. Educ. 51, 62-71. doi: 10.1177/00224669166 65588

Davies, J., and Graff, M. (2005). Performance in e-learning: online participation and student grades. Br. J. Educ. Technol. 36, 657-663. doi: 10.1111/j.1467-8535. 2005.00542.x

Dibbs, R. A., Glassmeyer, D., and Yacoub, W. (2013). Students' perceived utility of precision taught calculus. Qual. Rep. 18:101.

Doumen, S., Broeckmans, J., and Masui, C. (2014). The role of self-study time in freshmen's achievement. Educ. Psychol. 34, 385-402. doi: 10.1080/01443410. 2013.785063

Dziuban, C., Hartman, J., Moskal, P., Sorg, S., and Truman, B. (2004). "Three ALN modalities: an institutional perspective," in Elements of Quality Online Education: Into the Mainstream, eds J. R. Bourne and J. C. Moore (Needham, MA: Sloan Consortium), 127-148.

Ekwunife-Orakwue, K. C. V., and Teng, T. L. (2014). The impact of transactional distance dialogic interactions on student learning outcomes in online and blended environments. Comput. Educ. 78, 414-427. doi: 10.1016/j.compedu. 2014.06.011

Erbil, D. G. (2020). A review of flipped classroom and cooperative learning method within the context of Vygotsky theory. Front. Psychol. 11:1157. doi: 10.3389/ fpsyg.2020.01157

Ferguson, J. M., and DeFelice, A. E. (2010). Length of online course and student satisfaction, perceived learning, and academic performance. Int. Rev. Res. Open Distance Learn. 11, 73-84. doi: 10.19173/irrodl.v11i2.772

Ford, M. E. (1992). Human Motivation: Goals, Emotions, and Personal Agency Beliefs. Newbury Park, CA: Sage.
Fornell, C., and Bookstein, F. L. (1982). Two structural equation models: lisrel and pls applied to consumer exit-voice theory. J. Mark. Res. 19, 440-452. doi: 10.1177/002224378201900406

Fornell, C., and Larcker, D. F. (1981). Evaluating structural equation models with unobservable and measurement error. J. Mark. Res. 34, 161-188.

Fredricks, J. A., Blumenfeld, P. C., and Paris, A. H. (2004). School engagement: potential of the concept, state of the evidence. Rev. Educ. Res. 74, 59-109. doi: 10.3102/00346543074001059

Garrison, D. R. (2011). E-Learning in the 21st Century: A Framework for Research and Practice, 2nd Edn. New York: Routedge.

Garrison, D. R., Anderson, T., and Archer, W. (2000). Critical inquiry in a textbased environment: computer conferencing in higher education. Internet High. Educ. 2, 87-105. doi: 10.1016/s1096-7516(00)00016-6

Garrison, D. R., Cleveland-Innes, M., and Fung, T. S. (2010). Exploring causal relationships among teaching, cognitive and social presence: student perceptions of the community of inquiry framework. Internet High. Educ. 13, 31-36. doi: 10.1016/j.iheduc.2009.10.002

Garrison, D. R., and Kanuka, H. (2004). Blended learning: uncovering its transformative potential in higher education. Internet High. Educ. 7, 95-105. doi: 10.1016/j.iheduc.2004.02.001

Ghazal, S., Al-Samarraie, H., and Aldowah, H. (2018). "I am Still Learning": modeling LMS critical success factors for promoting students' experience and satisfaction in a blended learning environment. IEEE Access 6, 77179-77201. doi: 10.1109/Access.2018.2879677

Gist, C., and Bulla, A. J. (2020). A systematic review of frequency building and precision teaching with school-aged children. J. Behav. Educ. doi: 10.1007/ s10864-020-09404-3 [Epub ahead of print].

Gorges, J., and Kandler, C. (2012). Adults' learning motivation: expectancy of success, value, and the role of affective memories. Learn. Individ. Differ. 22, 610-617. doi: 10.1016/j.lindif.2011.09.016

Hair, J. F., Hult, G. T. M., Ringle, C., and Sarstedt, M. (2014a). A Primer on Partial Least Squares Structural Equation Modeling. Thousand Oaks, CA: Sage.

Hair, J. F., Hult, G. T. M., Ringle, C., and Sarstedt, M. (2017a). A Primer on Partial Least Squares Structural Equation Modeling (PLS-SEM), 2nd Edn. Thousand Oaks, CA: Sage.

Hair, J. F., Ringle, C., Sarstedt, M., and Gudergan, S. P. (2017b). ADVANCED Issues in Partial Least Square Structural Equation Modelling. Thousand Oaks, CA: Sage.

Hair, J. F., Sarstedt, M., Hopkins, L., and Kuppelwieser, V. G. (2014b). Partial least squares structural equation modeling (PLS-SEM): an emerging tool in business research. Eur. Bus. Rev. 26, 106-121. doi: 10.1108/ebr-10-2013-0128

Henseler, J., and Sarstedt, M. (2013). Goodness-of-fit indices for partial least squares path modelling. Comput. Stat. 28, 565-580. doi: 10.1007/s00180-0120317- 1

Hogarth, A. (2010). Education in a Competitive and Globalising World: Adopting Blended Learning for Collaborative Work in Higher Education, 1st Edn. New York: Nova Science Publishers.

Hong, S. C., and Park, Y. S. (2012). An analysis of the relationship between selfstudy, private tutoring, and self-efficacy on self-regulated learning. KEDI $J$. Educ. Policy 9, 113-144.

Hsu, L. L., and Hsieh, S. I. (2011). Factors associated with learning outcome of BSN in a blended learning environment. Contemp. Nurse 38, 24-34. doi: 10.5172/ conu.2011.38.1-2.24

Hsu, M. H., Ju, T. L., Yen, C. H., and Chang, C. M. (2007). Knowledge sharing behavior in virtual communities: the relationship between trust, self-efficacy, and outcome expectations. Int. J. Hum. Comput. Stud. 65, 153-169. doi: 10. 1016/j.ijhcs.2006.09.003

Jones, K. T., and Chen, C. C. (2008). Blended learning in a graduate accounting course: student satisfaction and course design issues. Account. Educ. J. 18, $15-28$.

Kerzic, D., Tomazevic, N., Aristovnik, A., and Umek, L. (2019). Exploring critical factors of the perceived usefulness of blended learning for higher education students. PLoS One 14:e0223767. doi: 10.1371/journal.pone.02 23767

King, S., and Arnold, K. (2012). Blended learning environments in higher education: a case study of how professors make it happen. Mid West. Res. Educ. 25, 44-59. 
Kozan, K., and Richardson, J. C. (2014). Interrelationships between and among social, teaching, and cognitive presence. Internet High. Educ. 21, 68-73. doi: 10.1016/j.iheduc.2013.10.007

Kubina, R. M., and Yurich, K. K. (2012). The Precision Teaching Book. Lemont, PA: Greatness Achieved Publishing Company.

Law, K. M. Y., and Breznik, K. (2017). Impacts of innovativeness and attitude on entrepreneurial intention: among engineering and non-engineering students. Int. J. Technol. Des. Educ. 27, 1-18.

Law, K. M. Y., and Geng, S. (2018). How innovativeness and handedness affect learning performance of engineering students? Int. J. Technol. Des. Educ. 29, 897-914.

Law, K. M. Y., and Geng, S. (2019). How innovativeness and handedness affect learning performance of engineering students? Int. J. Technol. Des. Educ. 29, 897-914. doi: 10.1007/s10798-018-9462-3

Law, K. M. Y., Geng, S., and Li, T. M. (2019). Student enrollment, motivation and learning performance in a blended learning environment: the mediating effects of social, teaching, and cognitive presence. Comput. Educ. 136, 1-12. doi: 10.1016/j.compedu.2019.02.021

Law, K. M. Y., Lee, V. C. S., and Yu, Y. T. (2010). Learning motivation in e-learning facilitated computer programming courses. Comput. Educ. 55, 218-228. doi: 10.1016/j.compedu.2010.01.007

Levy, Y. (2007). Comparing dropouts and persistence in e-learning courses. Comput. Educ. 48, 185-204. doi: 10.1016/j.compedu.2004.12.004

Li, J. Y., Ye, H., Tang, Y., Zhou, Z. K., and Hu, X. G. (2018). What are the effects of self-regulation phases and strategies for chinese students? A meta-analysis of two decades research of the association between self-regulation and academic performance. Front. Psychol. 9:2434. doi: 10.3389/fpsyg.2018.02434

Li, L. Y., and Tsai, C. C. (2017). Accessing online learning material: quantitative behavior patterns and their effects on motivation and learning performance. Comput. Educ. 114, 286-297. doi: 10.1016/j.compedu.2017.07.007

Lim, D. H., and Morris, M. L. (2009). Learner and instructional factors influencing learning outcomes within a blended learning environment. Educ. Technol. Soc. $12,282-293$.

Lin, Y. G., McKeachie, W. J., and Kim, Y. C. (2003). College student intrinsic and/or extrinsic motivation and learning. Learn. Individ. Differ. 13, 251-258. doi: 10.1016/s1041-6080(02)00092-4

Manganelli, S., Cavicchiolo, E., Mallia, L., Biasi, V., Lucidi, F., and Alivernini, F. (2019). The interplay between self-determined motivation, self-regulated cognitive strategies, and prior achievement in predicting academic performance. Educ. Psychol. 39, 470-488. doi: 10.1080/01443410.2019.15 72104

Mannion, L., and Griffin, C. (2018). Precision teaching through Irish: effects on isolated sight word reading fluency and contextualised reading fluency. Ir. Educ. Stud. 37, 391-410. doi: 10.1080/03323315.2017.1421090

Moos, D. C., and Marroquin, E. (2010). Multimedia, hypermedia, and hypertext: motivation considered and reconsidered. Comput. Hum. Behav. 26, 265-276. doi: 10.1016/j.chb.2009.11.004

Moskal, P., Dziuban, P., and Hartman, J. (2013). Blended learning: a dangerous idea? Internet High. Educ. 18, 15-23. doi: 10.1016/j.iheduc.2012.12.001

Muncey, J., and Williams, H. (1981). Daily evaluation in the classroom. Spec. Educ. Trends 8, 31-34. doi: 10.1111/j.1467-8578.1981.tb00442.x

Niemiec, T., and Lachowicz-Tabaczek, K. (2015). The moderating role of specific self-efficacy in the impact of positive mood on cognitive performance. Motiv. Emot. 39, 498-505. doi: 10.1007/s11031-014-9469-3

Nunnally, J. C. (1968). Psychometric theory. Am. Educ. Res. J. 5, 431-433.

Paglis, L. L., and Green, S. G. (2010). Leadership self-efficacy and managers' motivation for leading change. J. Organ. Behav. 23, 215-235. doi: 10.1002/j ob.137

Park, S. Y., Nam, M. W., and Cha, S. B. (2012). University students' behavioral intention to use mobile learning: evaluating the technology acceptance model. Br. J. Educ. Technol. 43, 592-605. doi: 10.1111/j.1467-8535.2011.01229.x

Patrick, H., Ryan, A. M., and Kaplan, A. (2007). Early adolescents' perceptions of the classroom social environment, motivational beliefs, and engagement. J. Educ. Psychol. 99, 83-98. doi: 10.1037/0022-0663.99.1.83

Porter, W. W., Graham, C. R., Spring, K. A., and Welch, K. R. (2014). Blended learning in higher education: institutional adoption and implementation. Comput. Educ. 75, 185-195. doi: 10.1016/j.compedu.2014.02.011
Putri, M. R., Luke, J. Y., and Sela, S. T. (2019). "Critical success factor in blended learning for English training: a systematic literature review," in Proceedings of the 1st International Conference on Advance and Scientific Innovation 23-24 April 2018, Medan, 1175. doi: 10.1088/1742-6596/1175/1/0 12251

Ramirez-Arellano, A., Acosta-Gonzaga, E., Bory-Reyes, J., and Hernandez-Simon, L. M. (2018). Factors affecting student learning performance: a causal model in higher blended education. J. Comput. Assist. Learn. 34, 807-815. doi: 10.1111/ jcal.12289

Raybould, E. C., and Solity, J. E. (1982). Teaching with precision. Spec. Educ. Trends $8,9-13$.

Raybould, E. C., and Solity, J. E. (1988). More questions on precision teaching. Br. J. Spec. Educ. 15, 59-61. doi: 10.1111/j.1467-8578.1988.tb00316.x

Rebecca, S., and Michelle, K. (2016). Precision teaching: does training by educational psychologist have an impact? Educ. Psychol. Pract. 32, 13-23. doi: $10.1080 / 02667363.2015 .1094651$

Reeves, J. R. (2006). Secondary teacher attitudes toward including English-language learners in mainstream classrooms. J. Educ. Res. 99, 131-143. doi: 10.3200/joer. 99.3.131- 143

Roberts, W., and Norwich, B. (2010). Using precision teaching to enhance the word reading skills and academic self-concept of secondary school students: a role for professional educational psychologists. Educ. Psychol. Pract. 26, 279-298. doi: 10.1080/02667363.2010.495215

Sabah, N. M. (2020). Motivation factors and barriers to the continuous use of blended learning approach using Moodle: students' perceptions and individual differences. Behav. Inf. Technol. 39, 875-898. doi: 10.1080/0144929x.2019. 1623323

Sarstedt, M., Ringle, C. M., Smith, D., Reams, R., and Hair, J. F. (2014). Partial least squares structural equation modeling (PLS-SEM): a useful tool for family business researchers. J. Fam. Bus. Strateg. 5, 105-115. doi: 10.1016/j.jfbs.2014. 01.002

Schneider, M., and Preckel, F. (2017). Variables associated with achievement in higher education: a systematic review of meta-analyses. Psychol. Bull. 143, 565-600. doi: 10.1037/bul0000098

Sharpe, R., Benfield, G., and Francis, R. (2006). Implementing a university e-learning strategy: levers for change within academic schools. Res. Learn. Technol. 14, 135-151.

Shea, P., and Bidjerano, T. (2014). Does online learning impede degree completion? A national study of community college students. Comput. Educ. 75, 103-111. doi: 10.1016/j.compedu.2014.02.009

Sherer, M., Maddux, J. E., Mercandante, B., PrenticeDunn, S., Jacobs, B., and Rogers, R. W. (1982). The self-efficacy scale: construction and validation. Psychol. Rep. 51, 663-671.

So, H. J., and Brush, T. A. (2008). Student perceptions of collaborative learning, social presence and satisfaction in a blended learning environment: relationships and critical factors. Comput. Educ. 51, 318-336. doi: 10.1016/j. compedu.2007.05.009

Swan, K. (2001). Virtual interaction: design factors affecting student satisfaction and perceived learning in asynchronous online courses. Distance Educ. 22, 306-331. doi: 10.1080/0158791010220208

Szeto, E. (2015). Community of inquiry as an instructional approach: what effects of teaching, social and cognitive presences are there in blended synchronous learning and teaching? Comput. Educ. 81, 191-201. doi: 10.1016/j.compedu. 2014.10.015

Torrisi-Steele, G., and Drew, S. (2013). The literature landscape of blended learning in higher education: the need for better understanding of academic blended practice. Int. J. Acad. Dev. 18, 371-383. doi: 10.1080/1360144x.2013.7 86720

Turvey, K., and Pachler, N. (2020). Design principles for fostering pedagogical provenance through research in technology supported learning. Comput. Educ. 146:103736. doi: 10.1016/j.compedu.2019.103736

Vaughan, N. (2007). Perspectives on blended learning in higher education. Int. J. ELearn. 6, 81-94.

Victoria Lopez-Perez, M., Carmen Perez-Lopez, M., and Rodriguez-Ariza, L. (2011). Blended learning in higher education: students' perceptions and their relation to outcomes. Comput. Educ. 56, 818-826. doi: 10.1016/j.compedu. 2010.10.023 
Wei, H. C., and Chou, C. (2020). Online learning performance and satisfaction: do perceptions and readiness matter? Distance Educ. 41, 48-69. doi: 10.1080/ 01587919.2020 .1724768

Weiner, B. (1990). History of motivational research in education. J. Educ. Psychol. 82, 616-622. doi: 10.1037/0022-0663.82.4.616

Wentzel, K. R., Battle, A., Russell, S. L., and Looney, L. B. (2010). Social supports from teachers and peers as predictors of academic and social motivation. Contemp. Educ. Psychol. 35, 193-202. doi: 10.1016/j.cedpsych.2010.03.002

Williams, E. A., Duray, R., and Reddy, V. (2006). Teamwork orientation, group cohesiveness, and student learning: a study of the use of teams in online distance education. J. Manage. Educ. 30, 592-616. doi: 10.1177/1052562905276740

Wood, R., and Bandura, A. (1989). Social cognitive theory of organizational management. Acad. Manage. Rev. 14, 361-384. doi: 10.2307/258173

Xenos, M., Pierrakeas, C., and Pintelas, P. (2002). A survey on student dropout rates and dropout causes concerning the students in the course of informatics of the Hellenic Open University. Comput. Educ. 39, 361-377. doi: 10.1016/s03601315(02)00072-6

$\mathrm{Xu}, \mathrm{D}$., and Jaggars, S. S. (2011). The effectiveness of distance education across Virginia's community colleges: evidence from introductory college-level math and English courses. Educ. Eval. Policy Anal. 33, 360-377. doi: 10.3102/ 0162373711413814

Yang, J. C., Quadir, B., Chen, N. S., and Miao, Q. (2016). Effects of online presence on learning performance in a blog-based online course. Internet High. Educ. 30, 11-20. doi: 10.1016/j.iheduc.2016.04.002
Yildirim, Z. (2005). Hypermedia as a cognitive tool: student teachers' experiences in learning by doing. Educ. Technol. Soc. 8, 107-117.

Yuan, C. H., Wang, D. J., Mao, C. Y., and Wu, F. X. (2020). An empirical comparison of graduate entrepreneurs and graduate employees based on graduate entrepreneurship education and career development. Sustainability 12:10563. doi: 10.3390/su1224 10563

Yuan, C. H., and Wu, Y. J. (2020). Mobile instant messaging or face-to-face? Group interactions in cooperative simulations. Comput. Hum. Behav. 113:106508. doi: 10.1016/j.chb.2020.106508

Zimmergembeck, M. J., and Locke, E. M. (2007). The socialization of adolescent coping behaviours: relationships with families and teachers. J. Adolesc. 30, 1-16. doi: 10.1016/j.adolescence.2005.03.001

Conflict of Interest: The authors declare that the research was conducted in the absence of any commercial or financial relationships that could be construed as a potential conflict of interest.

Copyright (c) 2021 Yin and Yuan. This is an open-access article distributed under the terms of the Creative Commons Attribution License (CC BY). The use, distribution or reproduction in other forums is permitted, provided the original author(s) and the copyright owner(s) are credited and that the original publication in this journal is cited, in accordance with accepted academic practice. No use, distribution or reproduction is permitted which does not comply with these terms. 


\section{APPENDIX A}

TABLE A1 | Precision teaching survey instrument.

Part One

Five-point Likert-type scale 1 = strongly disagree, 2 = disagree, 3 = neutral, 4 = agree, 5 = strongly agree.

\begin{tabular}{|c|c|c|}
\hline List of items label & Initial items & Sources of reference \\
\hline PPT_1 & Teachers have clearly formulated learning requirements and goals in online learning course before class. & Kubina and Yurich, 2012 \\
\hline PPT_2 & The online learning system records the scores of my learning process. & \\
\hline PPT_3 & Teachers have pertinent teaching targeted at problems in self-learning online course in classroom teaching. & \\
\hline PPT_4 & Teachers re-examine the teaching effect after classroom teaching. & \\
\hline SE_1 & I can carefully finish self-learning and test on time. & Artino and Mccoach, 2008 \\
\hline SE_2 & In classroom teaching, I can carefully participate in course learning. & \\
\hline SE_3 & I can carefully finish the test after class as required. & \\
\hline SE_4 & I can often figure out some countermeasures whenever I have trouble in learning. & \\
\hline SE_5 & I believe that I can finish the learning task even there are interventions. & \\
\hline SE_6 & I can always find a method to have course learning even there are technical problems, such as internet lag. & \\
\hline SE_7 & I can often find several solutions for a learning problem. & \\
\hline LM_1 & When I succeed in finishing the course learning task, my learning motivation will be stimulated. & Law et al., 2019 \\
\hline LM_2 & When I succeed in finishing the task, my learning motivation will be stimulated. & \\
\hline LM_3 & I feel glad that I have taken the course. & \\
\hline LM_4 & I am very interested in the course content and it stimulates my initiative in learning the course. & \\
\hline LM_5 & The course can improve my ability and knowledge and stimulate me to learn the course. & \\
\hline $\mathrm{CP}_{-} 1$ & I can quickly acquire knowledge from course. & Garrison et al., 2010 \\
\hline CP_2 & I can search more course-related information via other means of learning (such as video, discussion and network). & \\
\hline CP_3 & I can find problems existing in the course. & \\
\hline CP_4 & I can connect all knowledge points learned from the course as a whole. & \\
\hline CP_5 & My level of knowledge can be reflected from course learning. & \\
\hline CP_6 & The course allows me to explore more thoughts and integrate my thoughts into the solutions. & \\
\hline CP_7 & The course fosters my excellent thinking ability. & \\
\hline SP_1 & The course gives me a chance to express myself. & Garrison et al., 2010 \\
\hline SP_2 & The course gives me a chance to formally interact with my classmates. & \\
\hline SP_3 & The course gives me a chance to non-formally interact with other students. & \\
\hline $\mathrm{SP}_{-} 4$ & The course provides enough cooperative learning and discussion activities. & \\
\hline SP_5 & I prefer to attend course activities. & \\
\hline SP_6 & I have a sense of belonging toward the course. & \\
\hline TP_1 & Teachers have clear instructions for the participation of classroom learning activities. & Garrison et al., 2010 \\
\hline TP_2 & Learning task allotted by the course has moderate difficulties. & \\
\hline TP_3 & The teaching flow of the course is innovative. & \\
\hline TP_4 & I am satisfied with course information transmission channels and means. & \\
\hline PERF_1 & I have enriched my knowledge through the course. & Law et al., 2019 \\
\hline PERF_2 & I have improved my relevant skills through the course. & \\
\hline PERF_3 & I have improved my thinking ability through the course. & \\
\hline
\end{tabular}

Part Two

\begin{tabular}{ll}
\hline Your gender & Male/Female \\
Your age group & Below 18;18-19;20-21;22-23; above 23
\end{tabular}

